\title{
Hiberno-Rossica: 'KNOWLEDGE IN THE CLOUdS' IN Old IRISH AND OLd Russian ${ }^{1}$
}

\section{GRIGORY BONDARENKO}

\section{Introduction}

The present discussion aims to deal with one rare example of formulaic similarities in Old Irish and Old Russian poetic speech. In the past few years several studies have appeared devoted to the question of Celto-Slavic isoglosses or correspondences in theonymics and mythopoeic language. The paper is devoted to two particular fragments in two Old Irish and Old Russian texts with a special emphasis on the semantics and on the poetic rules, which are common to both examples. An attempt is made to tackle the problem of a common Indo-European ancestry for the formula discussed and for the cultural realities, which this formula reflects.

\section{Immacallam in druad Brain ocus inna banfátho Febuil hóas Loch Febuil}

The first text is an Old Irish poem Immacallam in druad Brain ocus inna banfátho Febuil hóas Loch Febuil ('The dialogue of Bran's druid and Febal's prophetess above Loch Febuil', henceforth $I D B$ ). The poem has been collated and edited with a translation by J. Carney (1976) whose edition I will use in this paper. ${ }^{2}$ The Dialogue consists of eight stanzas, four uttered by Bran's druid, and four by Febal's prophetess (banfáith, both their names are unknown) as they contemplated Loch Febuil (Lough Foyle) which had inundated the ancient kingdom of Febal, Bran's father. It is remarkable that drui and fáith are often interchangeable in early Irish literature: both perform the function of divination. Nevertheless neither the druid nor the prophetess perform any divination in our text. They are preoccupied with the past and the hidden present rather than with the future. $I D B$ is preserved in two manuscripts whose versions of the account are very close: TCD MS. 1363 (formerly H. 4. 22) (H) (the sixteenth century), p. 48 cols. $a$ and $b$ and Nat. Lib. of Ireland Gaelic Ms. 7 (N) (the sixteenth - early seventeenth century), cols. 9 and 10. The poem belongs

\footnotetext{
All translations, unless otherwise noted, are mine.

2 Cf. also Kuno Meyer's edition (1913) from H. 4. 22.
} 
to the group of texts from the lost eighth-century manuscript Cin Dromma Snechta as becomes obvious from the words asin l.c. nicc 'from the same book hic' in MS. H. 4. 22. J. Carney (1976: 181) dated the text on linguistic grounds to the early seventh century at the latest. J. Carey (2002) on the other hand argues that there are no linguistic grounds to date the poem earlier than the eighth century, but he does not altogether exclude a seventh century date for the text in question. The quatrain which interests us is in deibide metre. Bran's druid is a character associated with knowledge, or 'faculty of cognition' (fius): at first he calls himself 'not a man of little knowledge' (ni ba-se fer fesso bic), then his knowledge flies to the high clouds, and finally reaches a pure well with jewels. Our interest lies in the second stanza of the poem ascribed to Bran's druid and devoted to the flight of his 'knowledge'. The following variants of the stanza are given from $\mathrm{H}$ (based on K. Meyer's and J. Carney's transcript) and from N. ${ }^{3}$ The edition below is based on J. Carney's and J. Carey's with minor variations.

H (p. 48, col. a)

Anubimmis i dún braín icol isinnuargaim fiadum ne naisc triunu dialuig mofius coard níúl-.

$\mathrm{N}$ (col. 9)

// argaim $h$. fiadhúnib nenaisscc

A nubimáiss indun broin. icóol issindu

triuna dialluith mufiss co hairdníula

Reconstructed text:

A nu mbímmis i nDún Brain

oc óul isind úargaim,

fíad dóinib ${ }^{4}$ nenaisc tríunu

dia lluid mo fius co ardníulu.

While we were in Bran's stronghold

drinking in the cold winter,

in the presence of people [my knowledge] bound strong men,

when my knowledge went to the high clouds.

\footnotetext{
3 The readings are based on J. Carney's transcript and my own reading of the textual images of the MS provided by ISOS project.

4 J. Carey's reads fiad fiadnuib 'in presence of witnesses' which corresponds to the legal connotations of nenaisc (see further) (Carey 2002: 76, 79-80).
} 


\section{The Lay of Igor's Campaign}

An Old Russian text to be compared is a fragment from the late twelfthcentury epic 'The Lay of Igor's Campaign' (Слово о пльку Игоревъ, Slovo o plsku Igoreve) (Biblioteka 1997: 254). The only manuscript containing the tale was lost in the fire of Moscow in 1812. The text has survived in a published edition of 1800 and a copy made for Catherine II before 1793 (its long manuscript history is rather akin to the transmission of Irish $I D B$, which is even longer: from the early seventh to the early seventeenth century). The relevant fragment concerns a poet Boyan (Боянъ) who supposedly was a poet at the court of Igor's father, Svyatoslav Yaroslavich. He was a composer of verses in the manner of the Scandinavian skalds and so could have been seen as an archetypal poet and seer. The author of Slovo refers to Boyan as his source of inspiration and as the custodian of traditional matter in the same manner as the early Welsh poet Aneirin, the author of the Gododdin, refers to Taliesin:

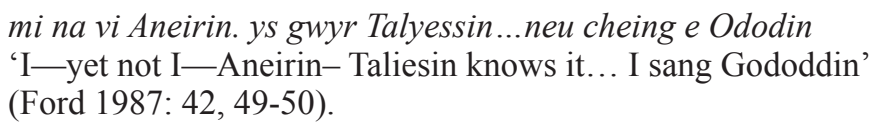

A similar personal existential uncertainty concerning his former self and his former knowledge is to be found in the very beginning of the druid's verses in IDB: Imbu messe, imbu mé nad fessed a aircdine? ('Was it I, was it myself that did not know its chieftains' generations?') (Carney 1976: 182). The poet is moved not only by the subject matter of his verses, but also by the almost magical circumstance of seeing himself singing them or knowing them (Borges 2000: 355). This reciprocity corresponds to the 'Illo Vergilium me tempore' ('I, in that time Virgil') (Georgics: IV 563) or to the 'Ille ego qui quondam' ('That I, who one day') written to preface the Aeneid. I give my translation of the relevant fragment from Slovo below.

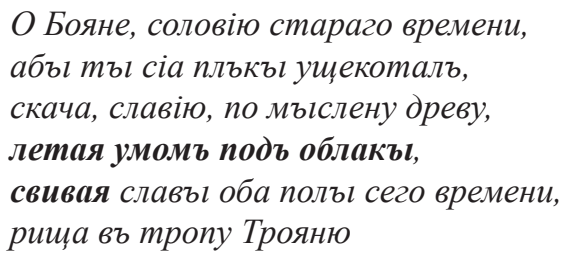


O Boyan, nightingale of an old time, if you were to chirrup to these hosts, leaping, o nightingale, along the mental tree,

flying with [your] intellect up to the clouds, weaving glories together from both halves of this time, rushing along Troian's path through the fields to the mountains.

\section{Priests, poets and the poetic formula describing the faculty of cognition}

Here we have two examples of the same formula relevant to poetic craft and the poet's gift. Both the Old Irish and the Old Russian examples quoted above have attracted attention of scholars and have been labelled as a 'shamanic experience' (Carney 1976: 184; Mac Mathúna 1985: 270; Encyclopedia 1995: 295). ${ }^{5}$ It is significant that both protagonists in these poems are not only poets: in Old Irish it is drui' 'druid' and in Old Russian it is въщщии 'wizard'. It is rather difficult to ascribe definite social, cultural and religious functions to either of these terms in early Christian Ireland or in mediaeval Rus'. One can evidently accept that druids in early Celtic societies held the function of priests. The same position is likely to have been held by druids in pre-Christian Ireland. ${ }^{6}$ As for the Irish material it seems that the poet and priest, as in many other Indo-European cultures, are interchangeable, especially as often in early Irish sources filid 'poets' and druïd are evidently synonymous and the two words are often used interchangeably (Plummer 1910: clxi-xii). One has to stress that the Irish poem ascribed to the druid is not necessary based on an authentic oral druidic text, although the existence of druids, seemingly in a degenerate form, is attested in seventhcentury Ireland.

In Old Russian no priestly functions for the въщій, въиунъ are attested. Nevertheless Old Russian вльсви (wizards, magi; stands for $\mu \dot{\alpha} \gamma о \imath$ in the Gospels where OI has druïd) definitely performed the functions of pagan priests sometimes associated with shamanic activity (Ivanov \& Toporov 1974: 64). To a certain extent both the OI and the OR narratives reflect this particular link between the activity of the poet and the priest with both

\footnotetext{
S. Mac Mathúna compared the druid's soul journey to the ecstatic experience found in the bailitype of tales (Mac Mathúna 1985: 270). The journey described in the poem is likely to have been performed with the use of occult technical skill fisidecht (Cf. DIL s.v.)

${ }^{6}$ Cf. the bull sacrifice episode in Serglige Con Culainn (Dillon 1953: 9).
} 
fragments referring to the poet's perception of the world, a specific cosmological scheme. What makes our two sources typologically similar in cultural and historical terms is their chronology (at least a widely accepted chronology). The seventh/eighth century for the Old Irish poem and the end of the twelfth century for the Old Russian tale means that they were composed approximately two centuries after the official acceptance of Christianity in both countries, when the influence of pre-Christian practices and beliefs might reasonably be deduced to have been at the same level in both cultures. Another common feature of the fragments devoted to Bran's druid and Boyan, the wizard, is that the information given is unique in the context of Early Irish or Mediaeval Russian literature.

The common poetic formula, which forms the centre of our interest, can be expressed on the grounds of the two texts as:

\section{FACULTY OF COGNITION FLIES/GOES TO/BENEATH (HIGH)}

CLOUDS and BINDS/WEAVES TOGETHER

Both variants of the formula, Old Irish and Old Russian, have the same agent 'faculty of cognition" (fius, $y_{M ъ}$ ). The Irish text is preoccupied with a notion of 'knowledge', 'cognition' and 'revelation' and it is rather difficult to use these English terms before looking more closely at OI fius. It is a derivative from IE *uids- 'seeing, knowing' (Mann 1987: 1534) and is cognate to Gaul. uis(s)u- 'knowledge' $<$ *uistu- $<*$ *uid-tu- (Delamarre 2001: 268). The radical uid- is attested also in OHG wizzi 'Verstand, Wissen', Skt. vidyâ 'knowledge' and in many other IE forms. One has to remember that the English word 'knowledge', which usually means the information available for those who search for it, renders OI fius rather inadequately. The latter often suggests esoteric, metaphysical perception. In insular Celtic sources this 'knowledge' is bestowed by inspiration and by revelation but not acquired gradually (MacKillop 1998: 254). Such 'knowledge' implies the perception of the entire universe in a single moment rather than the fragments of perception. The same 'knowledge' is alluded to in the Old Irish hymn 'Deer's Cry' (Fáeth fiada) ascribed to St. Patrick: cech fiss arachuiliu corp , anmain duini 'every knowledge that corrupts (?) man's body and soul' (Stokes \& Strachan 1903: 357.55).

\footnotetext{
The rendering of OI fius in the context of the poem is proposed by J. Carney (1976: 184).
} 
The word fius is several times mentioned by the druid in $I D B$ : he seems to be a 'knowledgeable' person here whereas in the prophetess' words we do not find any mention of knowledge. He is desperate that he 'did not know the chieftains' generations' of the drowned kingdom Mag Fuindsidi (nad fessed a aircdine). In a manner of litotes he proclaims that he 'was not a man of little knowledge until' he was 'defeated in the contest (dispute?)' (ni ba-se fer fesso bic co maidm form ind imbairic). J. Carney suggested that the 'contest' with the prophetess (banfáith) was a learned one, concerning genealogical lore, ${ }^{8}$ which is quite natural for Irish tradition (as in Immaccallam in dá thuarad 'The dialogue of the two sages').

At last after the flight his fius descends into a pure well with jewels and women, thus reaching the lower world after ascending to the upper one. This visionary (fius) journey constitutes a vertical structuring of space into three worlds: lower, middle and upper. ${ }^{9}$ There are several parallels to this kind of journey in insular Celtic traditions which are otherwise almost silent in regard to the vertical division of the world. Nevertheless these parallels are not concerned with 'knowledge' proper but tell us of the heroes' transformations into successive animal shapes belonging to different worlds. It is important, though, that in order to perform this transformation or metempsychosis the protagonist has to possess enough knowledge. I shall further discuss the Russian equivalents to these transformations and the figure of knowledgeable Boyan, the shape-shifter.

As for the Old Russian fragment we encounter a word with a different root, expressing nevertheless a similar concept. Old Russian yмъ had a range of meanings 'faculty of cognition, thought, soul, knowledge' and derives from Common Slavic *umъ (<*oumos), with a suffix - $m$ - as in CS *dymъ, *šumъ, cf. Lith. aитио̃ 'intellect, wisdom'. It seems to have an IE root *au- 'to understand, to perceive', the same as in Lith. ovyje, Russ. наяву 'in reality'; possibly Toch. B om-palokoñne 'meditation' (Chernykh 1993: 290; Pokorny 1959: 78).

The whole text of Slovo as well as our short Irish poem is full of references to 'knowledge', 'thought' and 'mental force'. Even the fragment discussed mentions 'the mental tree' (мъьслено древо), a very peculiar concept specific for Slovo. This 'mental tree' appears in the first verses of

\footnotetext{
8 Carney 1976: 182. The only contradiction is that the prophetess on her part does not seem to be a person of 'knowledge'; her functions are contemplation and memory.

9 For the meaning of the IE root *ueid- in the sense of 'vision', see Kalygin 2002: 110, 112.
} 
Slovo as connected with Boyan and his 'shamanic' journey as well. One of the best known and discussed episodes in Slovo refers to Boyan's poetic art and shape-shifting abilities:

Боянъ бо въщій, аще кому хотяще пьснь творити, то растькашется мъислію по древу, сърыль вълкомъ по земли, иизъимъ орломъ подъ облакъ.

For Boyan was a wizard (vatic), when he wished to create a song to anyone, he would flow with his thought through the tree, as a grey wolf along the ground, as a dusky eagle beneath the clouds (Biblioteka 1997:254).

One has to note a scholarly borrowing from Old Church Slavonic дръво instead of the use of the Old Russian дерево (ср. соловію: славію, on the other hand, an original might have had Old Russian дерево and соловію consequently).

This passage has always attracted discussion as to the significance of the word мълсль 'thought'; a possible suggestion was that it is a misreading for a dialectal Mzıcb 'squirrel' (Encyclopedia 1995: 295). One of the arguments for this reading was a parallel with a Scandinavian image of the Cosmic Tree Iggdrasil and a squirrel running along its bole as a messenger between the worlds. The image of the Cosmic Tree seems to be relevant here but the use and context of the word мъгсль in Slovo and in other Old Russian sources suggests the correct reading to be мъзслію. At first it is obvious that the speculative 'tree' of Boyan is the same concept, since it is twice referred to as: мысллію по древу: по мыслену древу. At the same time there are three other references in Slovo to the movement of thought (мысль):

Не мъсслію ти прелетьти издалеча..

Храбрая мълсль носить васъ умъ на дъло..

Игорь мъсслію поля мьрить (Biblioteka 1997: 262, 266)

Will you not fly with your thought from afar;

A brave thought carries your mind/intellect to the deed;

Igor measures the fields with his thought. ${ }^{10}$

This perception of thought is echoed by another Old Russian text 'The supplication of Daniel the Prisoner' (Слово Данила Заточеника), whose original variant was contemporary with Slovo: Бъцхъ мъıслію паря, аки орель по воздуху ('I was flying with my thought as an eagle through the

\footnotetext{
${ }^{10}$ Similar arguments based on structural determination in Gasparov 2000: 546.
} 
air') (Biblioteka 1997: 276). As we can see the 'flight of thought' is quite a usual expression in Old Russian as is the eagle as a classifier of the upper world, the world of inspiration and revelation. As for Boyan himself, in the first example he ascends the tree in the form of a nightingale (скача, славію, по мъсслену древу) rather than in that of a squirrel (cf. the pagan priest (?) Bogomil, called Nightingale for his eloquence in Tatischev's Russian History $(1994,112)$ ). The ornithological symbolism is a distinct feature of shamanic experience.

In Ireland the druid and fili seem to wear a garment made of bird feathers like the shamans of Northern Eurasia and Northern America. In Forbuis Druim Damhghaire ('The siege of Druim Damhghaire') Mogh Ruith, the blind druid of Munster is described as wearing a speckled bird's head-dress with fluttering wings and the hide of a brown hornless bull. $\mathrm{He}$ rises up into the sky performing what looks very much like a shamanistic feat (although we are told about his body's flight but not the flight of any 'shamanic soul') (Sjoestedt 1926: 110-112, § 117). At the same time among possible Slavonic parallels we find a similar image in Bulgarian survakary (сурвакары), performers at New Year festivals (which survived up to the present time) wearing hides, cattle bells, bright red rods and speckled birds' head-dress with fluttering wings (see picture 1, taken from Rybakov 1981: 265, 430).

The garment worn by Senchán Torpéist, the seventh century fili, is called tuigen, which is later explained in Cormac's Glossary as tuge én 'the thatch of birds', 'bird feathers', a mantle made of white and speckled feathers: up to his girdle, of the necks of wild ducks and from his girdle up to his neck, of their tufts (Stokes 1862: 43 = Sanas Cormaic 1059, 1231). Moreover the similar idea of the sacrificer becoming a bird and ascending to heaven is found in ancient India (Pañcavimiśa Brāhmana V, 3, 5; Eliade 1989: 404). Whatever the case Boyan's nightingale is likely to symbolise a shamanic soul.

As mentioned earlier, both Irish and Russian examples were labelled by scholars as a shamanic experience. During this shamanic trance, known to other traditions a shaman's soul is supposed to leave the body and to travel in the sky or in the underworld (Eliade 1989: 24). In Old Russian умъ can be rendered as 'soul'. It is plausible that OR умъ, мъисль and OI fius both refer to 'shamanic soul', a key concept of shamanism (cf. ON hamingja, hamr, fylgja; Lith. laimi-dalia) (Sergent 1995: 381). 
Another argument for the literal reading of the first Boyan passage in Slovo is the meaning of the verb растькатися 'to flow around': it looks like the wizard's thought flows in the tree itself, flowing like its sap. Here the tree evidently bears the functions of the arbor mundi connecting the worlds. The knowledge and the tree are bound together in a different area of Indo-European world in the name of Celtic priests or druids. Reconstructed Common Celtic *dru-wids 'knower of the tree/Tree' derives from IE *doru/*deruo- 'oak, tree' and IE root *ueid- 'to know, to see'. The 'Tree' here is a Cosmic Tree traversing and supporting three worlds of the Indo-European imago mundi, as well as encompassing the character of the Tree of Knowledge (Delamarre 2001: 126). This 'druidic' reference is significant enough for our Hiberno-Russian formula and Old Russian в ъъщи is likely to perform the same function of 'knowledge of the Tree' as his Celtic counterpart. At the same time the learned author of Slovo was fully aware of the biblical Tree of Knowledge, and if he did not literally mean it, the biblical Tree was thought of especially as Old Church Slavonic form $\partial p \npreceq в о$ shows the influence of the Scriptures.

The 'knowledge' or 'faculty of cognition' of both our protagonists ascends to the clouds (in Old Irish they are called more specifically: co ardniulu 'to the high clouds, cirrus'). This reflects a certain intermediate level of the upper world. It is important that clouds in the mythological consciousness are not similar to the sky, which is the unchangeable and stable upper world of the divine beings. Clouds reflect a more complex concept associated with human thought, with its spontaneous and sometimes quasi-chaotic movement. Clouds correspond to a human soul (anima) on the microcosmic level of Christian symbolism, as was stated in one Russian spiritual verse:

Пятая часть [человека], мысли, - от облацев.

Как облаиьь ходют на небеси ветром и ненастьем,

Такожда в человеке ходют мысли худые и добрые

(Golubinaya kniga, 1991: 220).

The fifth part [of a human being], thoughts come from clouds.

As clouds go on the sky driven by wind and bad weather,

So bad and good thoughts go in a man.

That is why our formula connecting clouds and human thought seems to be justified and universal. Due to these very reasons G. Bachelard 
(1990: 212) called clouds les "objets poétiques" les plus oniriques. Hence the great role of clouds in poetic and prophetic inspiration in both the Irish and the Russian fragments discussed. ${ }^{11}$

For Bran's druid the flight of his knowledge begins in the middle world of the mortals when he takes leave of his companions in Dún Brain. For the purposes of the narrative it is important that the company (presumably in the presence of the king Bran mac Febuil) was drinking in the cold winter (oc óul issind úargaim) in order to warm themselves as ól usually signifies drinking liquor. This specific preparation for the druid's shamanic ritual has parallels in other shamanic traditions although it seems to represent a new 'easy way' of realising a state of ecstasy (Eliade 1989: 401). A similar story is found in 'The Expulsion of the Dessi' when Díl the blind druid of Osraige drinks mead copiously and then reveals his secret predictions to his daughter (LU 4455-4457). In any event the druid's body remains with his companions in Dún Brain. The overall picture corresponds to P. Mac Cana's description of a specific Early Irish poetic practice in these terms:

The seer spoke from his divinatory trance, his inert and lifeless body may have been regarded merely as the passive medium by which the hidden knowledge was revealed (Mac Cana 1966: 81-82).

The word medium seems likely to be taken literally in our poem, where the druid functions as a medium for the other companions.

One has to note the different meanings of nél in Old Irish: it is either 'cloud' or 'ecstasy (sic!), swoon, stupor, death'. This range of meanings comes from the fact that nél is a relatively late borrowing from British (W. niwl, MW. nifwl) which word in turn was borrowed from Lat. nübilus 'cloud, confusion, haziness of mind'. ${ }^{12}$ It may be important that during their transformation several heroes in Old Irish tales ascend to the upper world usually in the form of a bird or of a fly/butterfly as in the case of Étaín. The most relevant examples are Tuán mac Cairill and Fintan mac Bóchna, well-known Irish primordial keepers of historical, poetic and prophetic knowledge, who, respectively, took the form of a hawk and an eagle during their metamorphoses (Carey 1984; Meyer 1907: 26). The power of spells and incantations are sometimes associated with clouds in Early Irish

\footnotetext{
${ }^{11}$ Skt. nabhas in Hindu and Tibetan tradition sometimes seems to mean 'inner space' of human head and human mind (Professor V. V. Vertogradova's suggestion, expressed orally at her seminar in Moscow State University).

${ }^{12}$ LEIA: N-8; hence dororchair Conall a nēl 'C. fell into a swoon' (Meyer 1906: 38).
} 


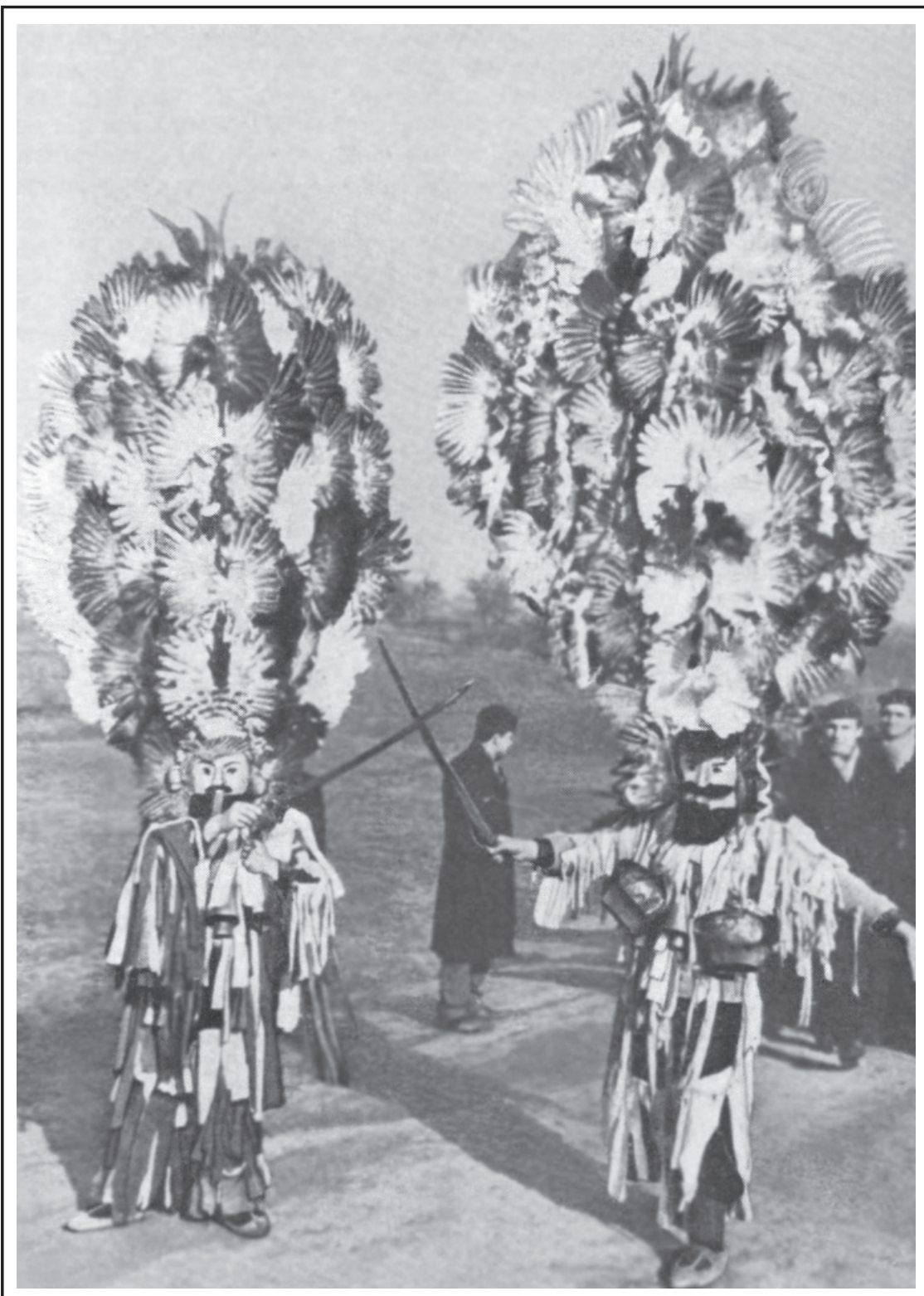

Picture 1

Bulgarian New Year festival: procession of the survakary at the time of the sacred bogach bread-making 
context as in a rosc from Forbuis Druim Damhghaire ascribed to Mogh Ruith, the druid.

Ferim brict a nirt nēl

I fashion a spell, its power of cloud. (Sjoestedt 1926: $110 § 114$ )

In Old Russian Boyan in the opening passage to Slovo flies to the clouds in the form of an eagle (шизымъ орломъ подъ облакъи). Thus the transformation does not contradict the shamanic flight of Boyan's intellect mentioned further on in the tale.

A suggested specific typological parallelism between Old Irish drui and Old Russian в ъщціи needs further consideration. We have already mentioned the most probable etymology of Common Celtic *dru-wids. Old Russian въичі similar to Celtic *dru-wids. въщщiu is a present participle from Old Russian and Old Slavonic въсти 'to know' (perfective aspect) ( $<$ Common Slavic *védti) deriving from IE root *u(e)idd- 'to know, to see, to note'. Thus въиціи originally a participle deriving from the perfective verb designates a person with transcendent knowledge. Another famous въщиi in early Russian tradition is the ninth-century Great-Prince Oleg (d. c. 912) of Scandinavian origin (ON Helgi 'holy', which is close to the semantics of в въщiu). ${ }^{13}$ Great-Prince Vseslav of Polotsk and Kiev (1030-1101) is also alluded to as въщиіи in Slovo (въща душа) where his abilities to turn himself into a wolf are mentioned.

Boyan, the 'wizard' (it seems not entirely correct to translate $в$ въщi 'wizard'), is also called in Slovo 'the grandson of Veles' (Voc.: въщеей Бояне, Велесовь внуче). This theonym leads to suggest another Celto-Slavic common mythopoeic and linguistic unit quite obvious and noticed already by several scholars, most notably R. Jacobson (1969: 588-589). Veles is a bipartite divine name with two constituents: IE root $*\left(\mathrm{H}_{2}\right)$ w-el- 'sight, insight, foresight, observance, vigilance' and es $\partial-o s / e s-u$ 'existent, essential'. The first root plays an important part in the archaic Celtic religious terminology both in theonyms and in the poetic nomenclature. The

\footnotetext{
3 'И прзваша Олга - въщии: бяху бо людие погани и невъигласи' ('And they called Oleg a wizard (въщии), because these people were pagan and ignorant') (Likhachov 1950: 907).
} 


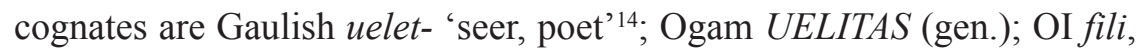
gen. filed (*ueletts / *ueletos) 'poet'. It is important to note that the filid in Early Ireland were also official custodians and transmitters of the mythological and synthetic historical tradition, displaying the ancient interdependence of poetry, divination and (quasi)-historical lore. The term fili was often interchangeable with druí. Moreover in OI the word fel $(<$ *uel) is attested in O'Davoren's glossary: fel ai ${ }_{7}$ seis, unde dicitur felmac .i. mac sesa 7 mac uadh i. aircetal (' $\mathrm{fel}$ 'poetic inspiration and sense', unde dicitur felmac, i. e. son of sense and son of poetic inspiration, i.e. poetry') (Stokes \& Meyer 1904: 344). As to fel one can consider a gloss from Early Irish laws: ani is feal laisin filid is seis no foircetal isin gnathbérla ("which is poetry with the poet is sense or instruction in the common language') (Laws: iv 358.4). Pupils of the druid Cathbad are mentioned in the Táin Bó Cuailnge as felmaic (iarmifoacht araile dia felmacaib do suidiu (Strachan \& O'Keeffe 1904-1912: 549). The term felmac ('the son of fel'), as R. Jacobson observes, presents a remarkably close correspondence to the formula 'grandson of Veles' (Велесовь внуче) in the 'The Lay of Igor's Campaign'. The only obstacle here is that felmac stands for 'pupil of poetry' and not for such a learned old poet as Boyan.

Moreover Volos/Veles is associated elsewhere in Russian sources with his own priests (вльсви) and with a shamanic/poetic syncretic tradition. According to a late Russian document 'Tale of the foundation of Yaroslavl' (TFY) based upon much earlier written and oral sources, a special priest (вълхвъ) served at the idol of Volos in Yaroslavl performing sacrifices of wild beasts, cows, and men at the unquenchable fire. Afterwards, the tale adds:

Сей волхв, яко пестун диавола, мудрствуя силою исконного врага, по исходищу воскурения жертвенного разумева и вся тайная, и глагола словеса приключшимся ту человецем, яко словеса сего Волоса (Ivanov \& Toporov 1974: 64).

This magician, as the devil's servant, sophisticating with the ancient enemy's force, after the exudation of the sacrificial smoke, perceived all the mysteries and uttered the words to the people nearby, as the words of this Volos.

\footnotetext{
${ }^{14}$ Cf. Veledā, a name of a prophetess, venerated by Germans, according to Tacitus (Germania: 8). This word in fact stands for a Celtic social institute borrowed by Germans (the border between Germans and Celts in Tacitus' time is rather uncertain) and adapted to their phonetics (-t- $>-d-)$ (Delamarre 2001: 261).
} 
It is remarkable that Old Russian въщцати (cognate to въщиiи) refers to sayings from an occult source, divine or demonic. What makes this example even more relevant is that Volos/Veles, associated with a shamano-poetic function, is present in TFY and 'The Lay of Igor's Campaign' only. Concurrently there is a reference to a priestly function, which is important for our comparison with OI drui, while Old Slavonic вльхвъ is likely to be cognate with Volos/Veles.

In the context of our comparison this correspondence leads to suggest close similarity of functions of Early Irish file and Old Russian въщчіи. The formula 'grandson of Veles' (Велесовь внуче) is likely to apply to all poets and singers qualified as въшіи (and possibly to the priestly class of вльсви originally). We have already discussed genetic similarity between *druwids and въщщi both of which preserve the semantics of the 'knowledge of the World Tree'. Furthermore I incline to doubt any sharp difference between file and druí in late pre-Christian Ireland and, more specifically, in the context of $I D B$.

OI nenaisc is $3 \mathrm{sg}$. pret. of the verb naiscid 'binds', which is often used in the laws, where its meaning is clearly figurative and connected with contract law. Korolyov (1995: 12-3) points out an Indic formula Sóma úpanaddhah 'bound Soma' which refers to the god and the plant sóma about to be sacrificed. Both OI and Old Indic verbs come from IE *uponedh- which can be classified as one of the ritual-judicial isoglosses common for Celtic and Indo-Iranian areas.

\section{Conclusion}

It is evidently significant that both poets in their shamanic flight bind or weave something/somebody together. In Irish poem it is the audience that is bound by druid's knowledge, the 'strong men' (warriors) are bound together and evidently are not able to move. It also seems likely that druid's knowledge binds only warriors without touching those present in the fort (Dún Brain) who might have been referred to as 'witnesses' (fiad fiadnuib or fiad doinib (?)). The themes of the Old Russian poem are the glories of the past and the future woven together by the poet with his craft of divination. In this manner Boyan fashions the destinies of his patrons and their warriors (this topos of weaving someone's destiny being widespread in many cultures although generally associated with female characters). 
In Old Irish we encounter 'the seven daughters of the sea', who 'fashion the threads of the long-lived youths' (dolbte snáthi macc n-aesmár) (Carey 1998: 136). It is remarkable that both Bran's druid and Boyan perform their art in the presence of warriors, their sovereign's band: tríun and плъкъl. Their art has a special significance for their fate and their wellbeing. The 'glories' (славъ $)$ woven by Boyan relate to the military victories and exploits. The druid of $I D B$ is associated with the king Bran (as his patron) and Boyan, the wizard, is portrayed as a court poet and singer of Russian princes.

The terms denoting the poetic creative art in IE languages are often borrowed from the vocabulary of different handicrafts. The poet may 'weave', 'sew', and 'fashion' a poem (Wagner 1970: 50-51; Korolyov 1994: 251). In Old Irish poetical craft might have been alluded to by the verb figid 'weaves' as in f(a)igfeirb fithir 'a teacher (of poetry) has woven a word' (ACC: 52). The symbolism of binding evident in $I D B$ can be interpreted by the shamanistic practice known throughout the world when the shaman binds a human soul (especially of a sick or dying person). This image is connected moreover with the magic of binding and bonds (Eliade 1968: $181 \mathrm{ff}$.).

University of Ulster

Coleraine

\section{Abbreviations}

ACC - Amra Choluimb Cille (see Stokes 1899-1900).

IDB - Immacallam in druad Brain ocus inna banfátho Febuil hóas Loch Febuil (see Carney 1976; Carey 2002; Mac Mathúna 1985). 


\title{
SUMMARY \\ ГРИГОРИЙ БОНДАРЕНКО
}

\author{
HIBERNO-ROSSICA: «ЗНАНИЕ В ОБЛАКАХ》 В \\ ДРЕВНЕИРЛАНДСКОЙ И ДРЕВНЕРУССКОЙ МИФОПОЭТИЧЕСКОЙ \\ ТРАДИЦИИ
}

\begin{abstract}
СТАТЬЯ ПОСВЯЩЕНА РЕДКОМУ ПРИМЕРУ СХОДСТВА МИФОПОЭТИЧЕСКИХ ФОРМУЛ В ДР ЕВНЕИР ЛАНДСКОЙ И ДР ЕВНЕР УССКОЙ ПОЭТИЧЕСКОЙ Р ЕЧИ. РАССМАТР ИВАЮТСЯ ДВА СООТВЕТСТВУЮЩИХ ФР АГМЕНТА ИЗ ДР ЕВНЕИР ЛАНДСКОЙ И ДР ЕВНЕРУССКОЙ ПОЭЗИИ, ОСОБ ОЕ ВНИМАНИЕ УДЕЛЯЕТСЯ СЕМАНТИКЕ И ПОЭТИЧЕСКИМ ПР АВИЛАМ, ОБЩИМ ДЛЯ ЭТИХ ДВУХ ПРИМЕРОВ. АВТОР АНАЛИЗИРУЕТ ФРАГМЕНТ ИЗ ДРЕВНЕИРЛАНДСКОЙ поэмы Immacallam in druad Brain ocus inna banfátho Febuil hóas Loch Febuil («Разговор друида Брана и пророчицы Февала над заливом Лох Февуль», VII в.) и фрагмент из древнерусской поэмы «Слово о полку Игореве». В статье поднимается проблема типологического и генетического родства обсуждаемой мифопоэтической формулы («знание в облаках»), еe древнеирландского и древнерусского вариантов (lluid mo fius co ardníulu; летая умомъ подъ облакы). Обсуждается возможная преемственность рассматриваемого феномена от общего индоевропейского мифопоэтического наследия, при этом учитываются и общие историко-культурные реалии раннесредневековой Ирландии и Древней Руси в период христианизации.
\end{abstract}

